\title{
Newspaper Reports Constructing Allegations and Responsibilities in the Pitcairn Island Sexual Abuse Trials
}

\author{
Keith Tuffin and Melanie Simons \\ Massey University, New Zealand
}

\begin{abstract}
$T^{\text {ne }}$ he Pitcairn sexual abuse trial was widely reported in New Zealand newspapers and this study examines constructions of both allegations and explanations of sexual abuse. Discourse analysis was used to study a database of 76 reports from the Dominion Post and New Zealand Herald. The analysis identified three discourses that co-articulate allegations of sexual abuse and attempts to explain and account for these allegations. The first discourse deals with reported allegations of childhood sexual abuse and trauma. The second discourse deflects responsibility from the accused men and lays open explanations drawing on the history and culture of Pitcairn. The third discourse constructs abuse as something that occurred because Britain failed to meet its responsibilities and provide adequate legal and moral guidance. These discourses are discussed in terms of the actions they perform in terms of reducing the level of personal responsibility for crimes of sexual abuse.
\end{abstract}

Keywords: Pitcairn Island, sexual abuse, cultural norm, social constructionism, media

The early years of this century saw Pitcairn Island receive more news media attention than previously, but for the wrong reasons (Fletcher, 2008). In 1999, British Constable Gail Cox visited Pitcairn and began interviewing women about alleged sexual abuse involving children as young as 5 years (Ansley, 2003; Middleton, 2005). The investigation led to legal charges and in 2004 a British court, sitting on Pitcairn Island, found six men guilty of sexual offences against underage girls that occurred between 1964 and 1999. Four of the accused received jail sentences and two were required to complete community service. An appeal was subsequently lodged with the Privy Council in London, based on the argument that Pitcairn was settled by descendants of the HMS Bounty mutineers and were, therefore, not subject to British law. The appeal was dismissed with charges of child rape, indecent assault and incest being upheld (Gregory, 2006). The trial was covered extensively in New Zealand newspapers, providing the opportunity to examine media reports of sexual abuse. This study aimed to identify constructions of sexual abuse and how key allegations and responsibilities were managed rhetorically. Our approach is informed by social constructionism and we foreground the analysis by outlining aspects of constructionist-inspired discourse analysis (Tuffin, 2005) and the unique history of Pitcairn.

\section{Social Constructionism and the Media}

Constructionists regard language as constitutive rather than representational (Austin, 1962; Lather, 1992). Constructionist epistemology highlights the possibility of multiple understandings, questions the extent to which unbiased observations are possible, and challenges the existence of truth as singular (White, 2004). Social constructionism argues that knowledge is contextually sensitive and culturally produced with our understandings inextricably located in linguistic practices. Constructionist enquiry aims to demonstrate how experience is constructed in, and through, language. In privileging the linguistic this style of research offers finegrained analysis identifying and examining commonly available discursive resources. Our theoretical claim is that discourse does not merely describe, but rather circumscribes understandings of our social realities. The approach is well suited for media analysis as it affords opportunities to interpret and understand the dynamics of power, knowledge, subjectivity, social practices and 
relationships (Hodgetts \& Chamberlain, 2003; Kitzinger, 2003; MacDonald, 2003; Parker, 1992; Potter \& Wetherell, 1994). Texts, such as newspaper reports, do not provide unambiguous, neutral accounts of events but are powerfully involved in shaping the way society views sexual abuse (Meyers, 1997). A key constructionist tenet is that language is a form of social action in its own right (Burr, 2003) that highlights how descriptions and accounts implicate cause, consequence and accountability (Edwards, 1997). Such implications and inferences are highly relevant to matters of legal accountability and responsibility.

While the story of the Bounty has been popularised in books and movies, Pitcairn Islanders regard the mutiny as part of island legend (Flood, Strong, \& Flood, 1999). In all mass media societies there are certain events that attract intense and prolonged interest. The media have a strong hand in constructing the reality of these stories, which carry powerful associations into everyday lives (Kitzinger, 2000). Inevitably, such associations are most powerful when anchored around important social issues. This is certainly the case for Pitcairn, whose story rests on a unique combination of historical, political and cultural circumstances.

\section{Pitcairn History}

In order to contextualise the analysis, it is important to consider the historical influences that contributed to Pitcairn sexual mores. In 1787 HMS Bounty, captained by William Bligh, left England for Tahiti to collect breadfruit. Stormy weather meant the Bounty remained in Tahiti for six months, during which time the crew formed relationships with local women. Shortly after their departure mutineers, led by Fletcher Christian, took control of the Bounty returning briefly to Tahiti where, accompanied by six Tahitian men and 12 Tahitian women, they set sail in search of a new home. Two months later, in the middle of the Pacific Ocean they found a small volcanic island located 200 miles east of its charted location on Admiralty maps. They had found the perfect hiding place: Pitcairn Island (Allward, 2000; Harvey, 2004).

The settlement of Pitcairn was not without problems. The Polynesian men were treated as slaves and they murdered Fletcher Christian and four other mutineers. Of the remaining four mutineers, one committed suicide, one was murdered and one died of natural cause. The surviving mutineer, John Adams, remained on the island with 10 women and 23 children (Allward, 2000). In response to increasing malcontent, Adams began bible readings at which he proclaimed himself as leader. The community was peaceful and throughout the early 1800 s saw a number of British ships visiting (Chauvel Carlsson, 2000).

With the opening of the Panama Canal in 1914 Pitcairn became the halfway point for ships travelling between Europe and New Zealand and cruise ships visited regularly. Increased exposure to outside influences saw Pitcairn culture move from its Tahitian roots, with New Zealand school curricula adopted and improved medical care. Tahitian attitudes to sex are important to consider since Tahitian girls reach puberty at around 11 or 12 years, and boys two years later (Lummis, 1997). At about this age sexual activity was seen as normal, with incest being the only taboo.

Currently, Pitcairn is a community of around 50 people who, due to extreme remoteness, have limited contact with the outside world. Pitcairn is the final British colony in the Pacific and has a history of both flight from, and dependence on, the British Crown. The history of Pitcairn is clearly important, as is Pitcairn law. The 1838 Constitution formally acknowledged Pitcairn as a British possession, protected by the Crown. In 1897, the first instance of serious crime occurred when an islander murdered his wife and child. A judicial commissioner from Fiji found the man guilty and sentenced him to death. When the laws were revised in 1904, seduction of a girl under 14 became an offence. Rape cases were referred to the High Commissioner's Court for the Western Pacific. In 1970, the administration of Pitcairn was transferred to New Zealand. The British High Commissioner in New Zealand became the Governor of Pitcairn. Provision was made for a Supreme Court of Pitcairn, to be co-extensive with the English High Court of Justice (McLoughlin, 1971).

\section{Media Reports of Sexual Abuse}

One line of investigation among studies of media reports of sexual abuse has considered the question of how responsibility is managed in the language of the press. For example, Goddard and Saunders (2000) examined United Kingdom (UK) and Australian media reports of child abuse and found two common uses of language that minimised perpetrators' responsibility. One was the 'objectification' of children, with the pronoun 'it' rather than the gender of the child being used, and another was the deployment of words for adult interactions such as 'affair' and 'relationship' to describe what occurred between an adult and a child.

Language used in sexual assault trial judgments commonly works to reduce the level of responsibility of the perpetrator; for example, describing him as being under the influence of alcohol (Coates \& Wade, 2004), or portraying sexual assault as erotic, rather than violent (Bavelas \& Coates. 2001). Similar results were found by MacMartin and Wood (2005) in a discursive study of judicial sentencing of child abuse cases. Lea and Auburn (2001) analysed narratives of a convicted rapist and found a discourse of ambiguity about the nonconsensual nature of the event, which suggested the victim was partly to blame, having not been sufficiently clear in her rejection of sex. 
Thakker and Durrant's (2006) study of news coverage of sexual offending in New Zealand newspapers found a large percentage of reports focused on a small number of high-profile cases. Further, this study stressed how the production of news is 'framed' such that certain viewpoints are presented as important. Closely linked to the current study is Robison's (2004) research, which applied a feminist perspective to press reports of sexual abuse on Pitcairn. Robison examined reports from British, New Zealand and Australian newspapers, focusing on the ways sexual abuse was categorised, minimised and normalised. Robison argues that the issue of sexual abuse of girls younger than 12 is difficult to report, with the matter becoming diffused and thereby contributing to public denial. Simons, Tuffin and Frewin (2010) analysed reports of the Pitcairn sexual abuse trials, demonstrating how key discourses worked to highlight Pitcairn's mystique and the prolonged political tensions with Britain. Pitcairn was constructed as being in conflict with the imposition of British injustices. This historical context frequently took precedence with the trail becoming more about Pitcairn's struggle for survival than about accountability for sexual crimes.

The extant literature points to the salience of how responsibility is constructed within media reports of sexual abuse offending and there is some evidence suggesting perpetrator responsibility is commonly downplayed, which raises questions about the dynamics of why and how this occurs. Earlier studies of reports of the Pitcairn sexual abuse trials have highlighted the difficulties around reporting underage sex and have documented the way in which the trials were dominated by ongoing tensions between Islanders and the British. Marks (2009) suggests reports were consistent with a 'David and Goliath' metaphor. Collectively, these studies demonstrate how media reports powerfully frame important issues of accountability, responsibility and guilt. The current study sought to extend the study of constructions of culpability by examining newspaper reports of the sexual abuse trial to see how these were constructed with respect to the management of responsibility and blame.

\section{Methodology}

Using search terms 'Pitcairn and trial' and 'Pitcairn and sex $^{\star}$ abus $^{\star}$ or rape', newspaper articles were located through an electronic database (Newztext Newspapers), covering the New Zealand Herald and the Dominion Post. The dataset comprised 76 articles collected between May 2001, when the first article appeared, and May 2005 when the verdicts were reached. Data was analysed discursively (Potter \& Wetherell, 1987), an approach increasingly used by psychologists interested in the social/linguistic constitution of lived realities (Macleod, 2002). While Macleod notes there is no definitive method of analysis, our analysis was concerned with text as social practice with a focus on the performative, rhetorical and constructive aspects of language. Linguistic variation is important as are the ways language use promotes certain viewpoints (Potter \& Wetherell, 1994).

Newspaper articles were coded manually (Tuffin \& Howard, 2001). Coding necessitated close reading of the text, a prerequisite for analysis, and organising the data into coding categories (Potter \& Wetherell, 1987). Coding identified systematic themes, tropes and resources available in the reports. Consistent with MacDonald's (2003) notion of media discourse as a system of communicative practices, discourses were defined as coherent systems of meaning that are in competition with other discourses (Parker, 1992; Tuffin, 2005). Dominant discourses construct versions of events that become regarded as a 'factual' retelling of events. Three key discourses are discussed: allegations of sexual abuse, the influence of cultural norms and sexual abuse as a British responsibility. Examples of these discourses are presented through analysis of the following extracts that were chosen for their explanatory and illustrative properties.

\section{Allegations of Sexual Abuse}

Our analysis begins with these claims, which were pivotal in framing not just the legal case but also stories backgrounding Pitcairn and its cultural heritage. Complainants' voices were reported most frequently in the month leading up to the guilty verdicts, reflecting the presentation of evidence in court. Complainants' evidence was far from simple: some reports involved allegations of sexual abuse, others reported members of the community turning a blind eye to abuse and, controversially, some complainants withdrew their testimony. The allegations of underage sexual abuse and the associated psychological nuances are considered next.

\begin{abstract}
A former Pitcairner yesterday painted a picture of a wretched childhood in which she was frequently thrashed at home and sexually assaulted by several older men on the island. (New Zealand Herald, October 13, 2004)

Statements by women who endured wretched childhoods on Pitcairn were read out ahead of sentencing tomorrow. One woman raped 40 years ago by several men including Steve Christian said: 'I sometimes have an urge to drive into a brick wall and end the pain'. She said of her abusers: 'They robbed me of my childhood'. (Herald, October 28, 2004)
\end{abstract}

In Extract 1 the complainant's evidence is prefaced by positioning her as being a former member of the community who suffered violence in addition to sexual abuse. Locating her as a former islander is significant in raising issues of loyalty to the Pitcairn community and its traditions. The violence is linked, presumably, to her own family as this is reported as taking place at home. The allegation of sexual abuse is linked to 'several older men' suggesting repeated abuse by multiple abusers. The second extract offers further bleak evidence from victims who suffered 'wretched' childhoods. One woman claims 
to have been raped by multiple perpetrators, the effect of which has been sustained over decades with talk of suicide and claims of a stolen childhood.

While the first two extracts are clear about the complaints and position the women as victims who suffered negative consequences, not all complainants spoke with a unified voice nor was their testimony without controversy. One aspect of the controversy was linked to claims that practices of underage sex were commonly concealed and Extract 3 highlights this positioning of Pitcairn men as highly controlling and immoral.

'It was ingrained, their way of life, and they tried to hide it.
The grandmothers claim they had their turn and the next
generation must endure it. The men controlled everything
and immorality on the island was very high'. (New Zealand
Herald, September 27, 2004)

Abuse is characterised as an integral part of life and is constructed as intergenerational with successive generations required to 'endure' and simply accept this as turn-taking. While primary responsibility rests with the men who are described as controlling 'everything', island women are implicated through their acceptance and involvement in attempts to hide mistreatment of young girls. Concealment also features in the next extract.

\begin{abstract}
'It was known generally that those incidents happened on the island, and nothing was done about it,' she said. 'It was shoved under the carpet. What good would it have done for me if I had reported it? I knew nothing would have been done about it, because of previous experience on the island. It was an act that everybody on the island knew was happening, and nobody wanted to talk about it and say it was wrong and deal with it'. (New Zealand Herald, October 5, 2004)
\end{abstract}

The speaker claims widespread knowledge of abuse, qualified as something 'generally known'. Further into the extract the extent of knowledge becomes complete with the extreme case formulation (Pomerantz, 1986) that 'everybody' knew, and rather damagingly this was not acted on. The speaker deplores this inaction and complains that it was purposefully hidden with the analogy of this being concealed under the 'carpet'. This suggests a dirty secret that was awkward for the community but, as Fletcher (2008) notes, this community has a longstanding culture of secrecy. The speaker addresses her own inaction by claiming helplessness and the futility of reporting victimisation. In effect, she complains that silent witnesses, of whom she is one, contributed to ongoing sexual abuse as inaction meant victims remained helpless.

Collective silence and inaction seem difficult to understand but, as the next extract shows, Pitcairn is a highly interdependent, tight community and any legal action could potentially have devastating effects on the community. In Extract 5 we see explanations for complaints being withdrawn.

'My reasons for withdrawing are simply that this whole mess could destroy our tiny community', she said. Another witness to have withdrawn her co-operation said the men operated the longboats - the only way on and off Pitcairn. If they were imprisoned, the island would have to be abandoned. (New Zealand Herald, March 22, 2003)

Positioning herself as a guardian of the community the speaker employs a 'greater good' argument in suggesting the legal case could destroy the island. A more specific reason is attached to the withdrawal of another complaint based on the pivotal importance of the longboats that would not be able to operate if the men were imprisoned. Since there is no dock or wharf the movement of people and essential goods relies on these boats, making them a key lifeline. The fear of prosecution and imprisonment threatened this service and the viability of life on Pitcairn. Thus the 'greater good' is a summary of the solution to the conflict between wanting justice for the victims of sexual abuse and maintaining life on the island. These conflicts reflect the analytic concept of dilemma of stake (Edwards \& Potter, 1992), which makes explicit the point that statements are never neutral in their impact. The speaker in Extract 5 acknowledges conflicts involved between seeking legal recourse for sexual wrongdoing and ensuring the viability of the island. The solution for this speaker is a course of action based on the pragmatism of maintaining life on Pitcairn. Further controversy is evident in the next extract where the speaker implicates the police in attempting to establish false allegations.

'They said they had insufficient evidence against one particular person and can I make up a false allegation against him. I said no, I could not do that and in fact I wanted to withdraw my statement from the cases they were trying to set up', she wrote in her complaint, which she also sent to the Herald. The victim, the first to speak publicly, alleges she was abused on the island as a child, but did not want to reveal details. She had been harassed and humiliated by the police, she wrote. She has also complained to the Kent police in Britain. '... they have hurt all of us deeply in the way they have gone about this and so I'm lashing back the only way I know how', she told the Herald. In a separate letter, her husband said he heard the officers ask her to make a false statement. That was utterly and truly disgusting. (New Zealand Herald, March 23, 2003)

This extract includes allegations of sexual abuse but focuses more extensively on the misconduct of the police who reportedly attempt to fix evidence and pervert the course of justice. The woman's allegations are supported by her husband who claims to have overheard the police impropriety. While this is a serious allegation it effectively swamps the claims of sexual abuse and raises the possibility that other aspects of the case were also 'worked up', thereby raising doubts about the authenticity of the evidence. The strength and determination of the women is acknowledged in the next extract.

Mr Vinson paid tribute to 'the courage of a group of women who have stood firm and said "enough is enough", despite the personal cost to themselves and their families. Two NZ 
police officers phoned the victims to tell them of the verdicts. Senior Constable Karen Vaughan told TVNZ: 'They were all extremely relieved, as if a lifetime of emotional turmoil has been concluded'. (New Zealand Herald, October $26,2004)$.

This extract serves the purpose of a coda, in providing a final strand to the complexities around the allegations of sexual abuse. Praise for the strength and determination of the complainants comes from both the prosecuting lawyer and the police. Most noteworthy is the acknowledgment of their commitment and the considerable costs involved. Implicit in these tributes is an awareness of the difficulties involved in defying the longstanding traditions of Pitcairn culture and the tight-knit community that upheld practices which came to be judged as morally and legally unacceptable. While this discourse perhaps lacks regularity, the marked variability within complainants' stories highlights the levels of ambiguity around the accusations. In underscoring the diverse and highly textured ways in which the allegations were constructed the analysis gives voice to the complex subject positions taken up by the victims. Next, the analysis considers discourses that sought to provide explanations that implicate historical patterns laying the blame with early cultural sexual mores and highlighting the lack of enforcement of British laws.

\section{Sexual Abuse as a Cultural Norm}

This discourse constructs underage sex as part of Pitcairn culture. Complainants are portrayed as having made accusations following their departure from Pitcairn and exposure to 'outside' cultural influences. The inclusion of voices of Pitcairn women (who are not complainants) stress the normality of underage sex and constructs it as not requiring the allocation of blame.

It is understood that the allegations involve widespread child abuse going back many decades. Though British officials insist that the age of consent on Pitcairn has always been 16, it is understood that Pitcairn girls are considered old enough for sex once they turn 12. (Dominion Post, June 2, 2001)

They have a dialect and a way of life all their own, including allegations of a tradition of under-age sex among children as young as 10 or 11. (New Zealand Herald, May 10, 2003)

Both extracts speak to an established local culture in which sex with girls under 16 is acceptable. In Extract 8 the age of consent is posited as being 12 with this pairing of understanding and consideration working to suggest acceptance. This contrasts with the insistence of, unspecified, British officials who state the age of consent has always been 16. Differing cultural expectations, practices and mores are also evident in Extract 9 that locates the lower age of consent within a broader list of cultural differences of language and lifestyle. The rhetorical effect is to embed underage sexual activity as one of many different cultural practices and therefore unexceptional. Interestingly, the phrase 'under-age sex' rather than more emotive alternatives such as 'rape' or 'child abuse' are employed, and this locates the report as dealing with simply a matter of cultural difference, rather than something that seeks to invoke potential emotional impact. Reflexively we note this phrase is consistent with connotations dictated by law in countries where the age of consent is 16 , while acknowledging the possibility that for other cultures this might be different. Youthful sexual activity is constructed as a 'tradition', suggesting a wellaccepted norm. The inclusiveness of the term 'children' opens the possibility of abuse as well as loving relationships (see Extract 12) driven by early sexual maturity. This possibility does important work in shaking the foundations of the abusive stereotype of an older man and young girl. It also means that not all 'under-age sex' was abusive and the phrase becomes less sinister. Cultural and historical relativities are illustrated with the next two extracts that construct the threshold for sexuality due to biological maturation.

All the defendants, meanwhile, have pleaded not guilty,
claiming the case is based on a profound misconception.
They argue that the island's culture is still influenced by its
part-Polynesian roots and that girls become sexually mature
early. (New Zealand Herald, September 27, 2004)

In Turkey you can marry at 11 . Different countries have their own way of life. (New Zealand Herald, August 25, 2002)

Extract 10 is closely linked to the defendants' proclaimed innocence and the view that the case is misguided. The argument is made that Pitcairn culture derives from Polynesian traditions of early sexual maturation and there exists a cultural sexual norm that is different, not necessarily wrong or illegal. Another cultural tradition is cited in Extract 11 where it is claimed Turkish society condones underage sex within marriage. Marriage has a positive ideological loading through associations with respectability and formal links with public ceremony, legality and social approval. The rhetorical effect of citing another culture with a youthful age of consent is to highlight the point of cultural relativity which, in turn, serves to undermine the moral and legal case against the accused. What they are accused of differs little from what is accepted practice in other cultures. The normalisation of early sexual activity is also illustrated in the next extract.

'It seems that it's been done right through the ages. It didn't seem wrong', he said. It had been a case of 'someone following on from someone else'. Even his parents started having sex at a young age. 'It seems as though it's pretty common'. (New Zealand Herald, October 9, 2004)

Extract 12 works to establish the longstanding tradition of underage sexual practices on Pitcairn. The historical reference suggests a cultural practice that has been passed down intergenerationally. This sexual more is constructed as accepted practice that provides a basis for judging it as morally acceptable, something bolstered by 
the speaker's claim regarding his parents' youth when they became sexually active. The strong inference being that a younger age of consent does not preclude the development of stable, loving relationships. Further, the report contains a claim regarding the commonality of this practice. Interestingly, while this is used in defence of the accused, the example makes clear reference to consensual sexual activity between same-aged partners, not an older man with a younger girl.

The next extracts construct the complainants as being influenced by external cultural standards and challenging the cultural lens through which we judge both our own and others' actions. Questions are raised about the timing of the complaints along with considerations based on constructions of a New Zealand culture of victimhood.

But if sex with girls from the time they turn 10 is part of the island culture, why are there now complaints? One theory is that increased travel and exposure to western mores through the videos of television shows sent to the island, have led girls to realise what has allegedly been done to them is wrong. (New Zealand Herald, June 30, 2001)

High flights of imagination are not needed to grasp how someone raised in the island's extraordinarily introverted culture could settle in New Zealand, absorb our culture of victimhood and be persuaded she had been seriously wronged. (New Zealand Herald, October 23, 2004)

Common to both extracts is the suggestion that concerns of illegality and sexual impropriety followed exposure to the world beyond Pitcairn. This construction extends the locus of responsibility to include wider cultural influences that portray underage sex as illegal. Exposure to the sexual standards of cultures beyond Pitcairn is posited as contributing to the developing awareness of wrong the girls suffered; not forgetting their adult status when the legal complaints were made. This interpretation is glossed as 'one theory' (among others) that rests on Pitcairn's geographical isolation and cultural insularity. This point is made explicitly in Extract 14, which advances the suggestion that victims' sense of having been wronged was heightened through exposure to New Zealand's culture of victimhood. This dynamic implies that culturally appropriate actions on Pitcairn were reevaluated following exposure to New Zealand culture. Not only is the age of consent different, but some believe New Zealand has a culture that fosters illusory victimhood (Pond, Frewin, \& Tuffin, 2009), which is constructed as persuasive in changing the minds of women who had not previously seen themselves as victims. Thus the attribution of responsibility moves from the accused men to external cultural influences that have the rhetorical effect of undermining the authenticity of sexual abuse claims. For New Zealand readers this provides a challenge to examine cultural biases and judgments of the accused who were also reported as having their views challenged, as the next extract illustrates.
Asked if he thought it appropriate for a man of his age to have sex with a girl of 13, he said: 'I regret it now. Times are changing. Things are moving forward, and obviously what we did then was not normal'. (New Zealand Herald, October 9,2004 )

Extract 15 questions the appropriateness of underage sex and the response cites awareness of changing times and contemporary regret, which is qualified as an after-thefact judgment. Historical actions are not disputed but judged, contemporaneously, as abnormal without any concession that this was wrong at the time. The speaker offers a plea of innocence within a context of changing times and standards. Under this view the case the sexual abuse was, arguably, blameless and victimless. This line of accountability is supported by claims from Pitcairn women that underage sex was normal. The next extract illustrates this point and speaks to conflict between local women and the complainants.

The women of Pitcairn Island are angry. They say the outside world has a skewed perception of how their tiny community functions. They are furious that their men, seven of whom go on trial tomorrow on child sex abuse charges, have been depicted as hardened criminals. But the island's women said yesterday that Pitcairn, Britain's last dependency in the South Pacific, had had a tradition of under-age sex since it was settled by the mutineers from in 1790. The meeting, attended by 13 women from three generations, was held at Big Fence, the home of Olive Christian, the wife of Pitcairn's mayor, Steve Christian. The message was that local girls mature sexually early on, and all the alleged victims had been willing participants. Darrlyn Griffiths, 28, said she started having sex at 13. Meralda Warren, 45, said she started at 12 . Nadine Christian, 32, said: 'It was just the way it was. It goes way back. It's been happening for generations and generations. The kids here don't have any entertainment'. (New Zealand Herald, September $29,2004)$

The emotional state of the island's women begins this report, based on negative portrayals of criminality directed towards 'their men'. While the women speak collectively, individual speakers are identified with direct quotations personalising the accounts. Underage sex is constructed as an intergenerational practice linked, originally, to the settlement of the island. The unified voice of the 'island's women' is separate from other women and, by implication, from the complainants. The message is that Pitcairn girls become sexually mature early and the victims were consenting. This claim goes beyond the generalities of early sexual maturation and local norms to the individual psychology of consent, which is highly salient to questions of responsibility and accountability. Finally, the suggestion is made that early sexuality is related to the lack of entertainment. Pitcairn women were not unqualified in their accounting of underage sex as an accepted tradition as the next extract shows.

The women hastened to add any non-consensual sex was wrong, and that it was 'sick' to have sex with a child before she reached puberty. (New Zealand Herald, September 29, 2004) 
Local women make unambiguous negative judgments regarding nonconsensual sex, and sex involving prepubescent girls. The word 'child' highlights the youthfulness and inappropriateness of sex with prepubescent girls, a notion warranting the derogatory judgment: 'sick'. These judgments position Pitcairn women as supporting the minimal standard of consent and also caring about young girls. These standards undermine claims the community failed its young women and thereby made them less culturally distant from New Zealand readers. The next discourse seeks to explain underage sex, not by attributing this to a specific cultural heritage but by pointing toward British responsibility.

\section{Sexual Abuse as British Responsibility}

Pitcairn's sexual abuse is portrayed, in this discourse, as a failure of British responsibility. Pitcairn's history of defying rules is deployed to suggest British authorities should have monitored the island more closely. The islanders themselves are positioned as naive regarding the legal age of consent and thereby having diminished responsibility.

Sarah says that, concerned for her daughter, she raised the subject with one man and was frozen out by the community. It was impossible for anyone to make a stand because there was no authority to turn to. She believes the British must share the blame for allowing Pitcairn's sexual culture to continue. (New Zealand Herald, August 25, 2002)

This report explains how the issue of sexual abuse was raised with a man; a choice we assume reflects his understanding and/or seniority within the community. Disappointingly, this results in community ostracism. Sarah has no further recourse and Britain is constructed as the governing body that failed to prevent abuse. Thus, abuse occurred through lack of appropriate governance and there was no 'authority to turn to'. This extract builds on the assumption of underage sex being accepted while also implicating Britain for failing to exercise its legal responsibilities, thereby sustaining the culture of sexual abuse. The word 'allowing' constructs British neglect as enabling the continuation of sexual abuse, a responsibility that should be shared. The next extract speaks to the question of ambiguity regarding the status of British law.

Defence lawyers will argue before the Pitcairn Supreme Court, sitting in Papakura, that English law was never enforced in the British colony and the men thus could not have known that rape was a serious criminal offence. (New Zealand Herald, April 19, 2005)

An argument is advanced that Pitcairn men were not aware of the seriousness or legality of underage sex. The lack of law enforcement suggests the men 'could not have known' that underage sex was a serious offence. Again, British responsibilities are prominent with the rhetorical effect of diminishing the level of accountability expected of local men. The use of the word 'rape' rather than 'underage sex' is interesting because it implies serious criminality. There is an element of disbelief in that statement, suggesting that the men must have known this was wrong, but perhaps they failed to understand the gravity of their wrongdoing. British responsibilities also feature in the next extract.

\begin{abstract}
Victoria University international law expert Tony Angelo says Britain has an obligation under a United Nations decolonisation agreement to assist Pitcairn in reaching a point where it is able to govern itself and determine its own future. It is a 'sacred' agreement, he says, which states that members who assume responsibility for the administration of territories must recognise that the interests of the inhabitants are paramount. Now is the time for Britain to step up to the block and help Pitcairn deal with its problems, he says. (Dominion Post, November 16, 2002)
\end{abstract}

Here the notion of assisting towards self-governance is a recommendation for a strong guiding hand, which has been notably absent. The task of guiding and educating the island community rests with the British, which is positioned as the mature nation with responsibilities toward the fledgling colony. This relationship invokes the parent-child metaphor that was evident throughout. The phrase 'now is the time' suggests such guidance has not been forthcoming and hints that the sexual abuse cases have been catalytic in this political process. British authorities are positioned as being aware of the need to take legal and moral responsibilities more seriously as they assist Pitcairn's move toward self-governance. The strong implication being that these duties have been previously neglected and the British have failed to take responsibility under the auspices of a highly revered United Nations decolonisation agreement.

\section{Discussion}

The analysis has identified three discourses that co-articulate allegations of sexual abuse and attempts to explain and account for these. The first discourse deals with the allegations based on women's reports of sexual abuse and trauma. Positioned as victims, the women reported difficulty in having their allegations heard as previous complaints were met with concealment and inaction. The reasons for hiding this issue are complex but include the possibility of ultimately serving as a threat to the island's viability since the accused were pivotal in operating essential services linking Pitcairn to the outside world. This concern echoes the point (Simons, Tuffin, \& Frewin, 2010) that the struggle for survival relied on the workforce of accused men. While positioned as victims the complainants were also, ironically, positioned as perpetrators of threat to the Pitcairn community. As initiators of the trial they were responsible for setting a process in motion that could threaten the continuation of life on Pitcairn and for this reason some complainants withdrew their evidence.

Details of the allegations appeared toward the end of the reporting period. While this omission reflects the 
presentation of evidence at trial, the preceding months saw the victims' voices absent, this void filled with competing discourses that constructed sexual abuse as a cultural norm rather than a horror inflicted on unwilling children. One controversial aspect of the allegations were the counter-allegations of police attempts to falsify evidence that cast doubt on the authenticity of the allegations. This was potentially damaging to the overall case as it raised the possibility that other allegations may have similarly been 'worked up' to bolster a legal case lacking substance. Interestingly, the report of this complainant is corroborated by a second voice, the victim's husband, the rhetorical effect being to make the allegation of evidence tampering seem more convincing.

The second discourse deflects responsibility away from the accused and lays open an explanation drawing on the history and culture of Pitcairn. Specifically, the discourse argues that underage sex was accepted practice, deriving from Tahitian cultural traditions stretching back to the original settlers. This tradition was normalised within the context of a younger age of consent being similar to other cultures that recognise early sexual maturation as being the basis for long-term loving relationships. Arguments around cultural and historical relativities are consistent with constructionist enquiry (Gergen, 1999) and are closely related to the historicity of childhood (Aries, 1962) and the ideological minefield associated with questions about the age of consent. Such considerations inevitably raise questions about the particular cultural lens that the court case imposed on intergenerational sexual practices on Pitcairn. It was argued the allegations were based on a misunderstanding and that what took place was different, but not necessarily wrong. The interpretive grey area opened up by this argument was supported by two further lines of rhetoric. First, the Pitcairn women who unambiguously condemned nonconsensual sex and sex with prepubescent girls, and second, Pitcairn men who acknowledged that times had changed and what had taken place previously was no longer acceptable. Under this view, questions of blame and responsibility become redundant since underage sex was regarded as normal at the time.

The third discourse constructs abuse as something that occurred because Britain failed to meet its responsibilities and provide adequate legal and moral guidance. This focuses on the power differential between Britain and Pitcairn extending the metaphor of Pitcairn as childlike, requiring the parental authority of the British to establish appropriate sexual standards. Further, it continues the line of argument that moves accountability away from the accused. In diffusing responsibility this discourse works to reduce the level of personal responsibility attributable to the accused. This weaving of culture, history and politics constructs responsibility as more widely shared and, while there is little doubt abuse took place, what is less clear is the extent to which this seen as wrong by those responsible at the time.

This analysis offers further evidence of media reports that operate to reduce the level of personal responsibility for crimes of sexual abuse (Robison, 2004). In considering the fractured discourse of the allegations and the diffused responsibility implied in the discourses of cultural relativities and the failure of the British authorities, issues of accountability are directed away from the individual blame and responsibility assumed by courts of law. Arguably, these news stories worked to more fully contextualise the sexual abuse trial, but in so doing lessened the degree to which individual perpetrators were responsible for their actions. Other victims were implicated with Pitcairn society threatened by the actions, ironically, of the abuse victims themselves. The prospect of individual punishment invoked a ripple effect highlighting wider community consequences that threatened to undermine the myth and reality of life on Pitcairn.

Of course, these reports are not simply about sexual abuse as the trial also entailed other agendas involving the unique politics and history of the island (Simons, Tuffin, \& Frewin, 2010). The complicity of the islanders in these crimes is weighed against the injustice of persecuting an entire community for the misdeeds of a few. The prevalence of discourses in diminishing personal accountability may inform readers of the wider influences operating, but may also simply provide a more interesting story than one of sexual abuse. This analysis offers evidence that individual responsibility was diminished through news reports, but also provides a detailed analysis of the dynamics of how this took place.

At one level the newspaper reports of the trial dealt with sexual abuse, but at other levels the reports invited readers to consider their own morals, judgments and expectations regarding the actions of others in a culture vastly different to that which readers inhabit. Readers most likely live in large metropolitan centres but key players in the trials came from a remote island, home for a small and intimate community. Different audiences and different psychologies are involved as the discourses of diminished responsibility and cultural context suggest. The analysis has shown the extent to which language circumscribes understandings and psychological knowledge of sexual abuse, enabling some interpretations while limiting others.

\section{References}

Allward, M. (2000). Pitcairn Island refuge of the Bounty mutineers. Stroud, UK: Tempus.

Ansley, B. (2003, July 26). The Pitcairn problem. New Zealand Listener, 189, 22-24.

Aries, P. (1962). Centuries of childhood. New York: Vintage Books.

Austin, J.L. (1962). How to do things with words. Oxford: Clarendon Press. 
Bavelas, J., \& Coates, L. (2001). Is it sex or assault? Erotic versus violent language in sexual assault trial judgments. Journal of Social Distress and the Homeless, 10(1), 29-40.

Burr, V. (2003). Social constructionism. New York: Routledge.

Chauvel Carlsson, S. (2000). Pitcairn Island at the edge of time. Rockhampton, Australia: Central Queensland University Press.

Coates, L., \& Wade, A. (2004). Telling it like it isn't: Obscuring perpetrator responsibility for violent crime. Discourse \& Society, 15, 499-526.

Edwards, D. (1997). Discourse and cognition. London: Sage.

Edwards, D., \& Potter, J. (1992). Discursive psychology. London: Sage.

Fletcher, L.M. (2008). Reading the news: Pitcairn Island at the beginning of the 21st Century. Island Studies Journal, 3(1), 57-72.

Flood, B., Strong, B.E., \& Flood, W. (1999). Pacific island legends. Honolulu, HI: The Bess Press.

Gergen, K. (1999). An invitation to social construction. London: Sage.

Goddard, C., \& Saunders, B.J. (2000). The gender neglect and textual abuse of children in the print media. Child Abuse Review, 9, 37-48.

Gregory, A. (2006, March 30). Pitcairn looks to break out of its isolation. The New Zealand Herald.

Harvey, C. (2004, October 20). The Pitcairn paradise, or an island of depravity. The New York Times. Retrieved April 18, 2009, from http://www.nytimes.com/2004/10/20/international/asia/201etter.html

Hodgetts, D., \& Chamberlain, K. (2003). Narrativity and the mediation of health reform agendas. Sociology of Health o Illness, 25(6), 553-570.

Kitzinger, J. (2000). Media templates: Patterns of association and the (re)construction of meaning over time. Media, Culture \& Society, 22, 61-84.

Kitzinger, J. (2003). Creating discourses of 'false memory': Media coverage and production dynamics. In P. Reavey \& S. Warner (Eds.), New feminist stories of child sexual abuse: Sexual scripts and dangerous dialogues (pp. 94-107). London: Routledge.

Lather, P. (1992). Postmodernism and the human sciences. In S.K. Vale (Ed.), Psychology and postmodernism (pp. 88-109). London: Sage.

Lea, S., \& Auburn, T. (2001). The social construction of rape in the talk of a convicted rapist. Feminism \& Psychology, 11, $11-33$.

Lummis, T. (1997). Life and death in Eden. Pitcairn Island and the Bounty mutineers. London: Phoenix.
MacDonald, M. (2003). Exploring media discourse. London: Hodder \& Stoughton.

MacMartin, C., \& Wood, L.A. (2005). Sexual motives and sentencing. Judicial discourse in cases of child sexual abuse. Journal of Language and Social Psychology, 24, 139-159.

McLoughlin, D. (1971). Laws of Pitcairn, Ducie and Oeno Islands. The Pitcairn Island Study Centre. Retrieved August 23, 2005, from http://library.puc.edu/pitcairn/pitcairn /govt-history/

Macleod, C. (2002). Deconstructive discourse analysis: Extending the methodological conversation. South African Journal of Psychology, 32 (1), 17-26

Marks, K. (2009). Lost paradise. New York: Free Press.

Meyers, M. (1997). News coverage of violence against women. Engendering blame. Newbury Park, CA: Sage.

Middleton, J. (2005, March 22). Picking up the pieces on Pitcairn Island. New Zealand Herald.

Parker, I. (1992). Discourse dynamics: Critical analysis for social and individual psychology. London: Routledge.

Pomerantz, A.M. (1986). Extreme case formulations: a new way of legitimating claims. Human Studies, 9, 219-230.

Pond, R., Frewin, K., \& Tuffin, K. (2009). Sexual abuse, counselling and compensation: Discourses in New Zealand newspapers. Feminism and Psychology, 19(1), 29-47.

Potter, J., \& Wetherell, M. (1987). Discourse and social psychology. Beyond attitudes and behaviour. London: Sage.

Potter, J., \& Wetherell, M. (1994). Analyzing discourse. In A. Bryman \& R.G. Burgess (Eds.), Analyzing qualitative data (pp. 47-56). London: Routledge.

Robison, V.R. (2004). An age of consent. Press representations of endemic sexual abuse of young girls by Pitcairn Island men. Unpublished master's thesis, Massey University, Palmerston North, New Zealand.

Simons, M., Tuffin, K., \& Frewin, K. (2010). Newspaper constructions of sexual abuse on Pitcairn Island. Australian Journal of Communication, 37(1), 95-110.

Thakker, J., \& Durrant, R. (2006). News coverage of sexual offending in New Zealand, 2003. New Zealand Journal of Psychology, 35, 28-35.

Tuffin, K. (2005). Understanding critical social psychology. London: Sage.

Tuffin, K., \& Howard, C. (2001). Demystifying discourse analysis: Theory, method and practice. In A. McHoul \& M. Rapley (Eds.), How to analyse talk in institutional settings: A casebook of methods (pp. 196-205). London: Continuum International.

White, R. (2004). Discourse analysis and social constructionism. Nurse Researcher, 12(2), 7-16. 